\section{Looking again at current practice in project management}

Current practice in project management

\author{
Joyce Fortune and Diana White
}

Technology Management Research Group,

Department of Communication and Systems, The Open University, Milton Keynes, UK

Kam Jugdev

Centre for Innovative Management, Athabasca University, St Albert, Canada, and

Derek Walker

School of Property, Construction and Project Management, RMIT University City Campus, Melbourne, Australia

\begin{abstract}
Purpose - The purpose of this paper is to report the findings of a survey designed to: capture the "real world" experiences of people active in project management (PM) in Australia, Canada and the UK; determine the extent to which those involved in the management of projects make use of the methods and techniques that are available; and discover how effective the methods and techniques are felt to be.

Design/methodology/approach - A questionnaire comprising 24 questions with a mixture of yes/no, Likert-scale, multiple choice and open questions was developed. These were designed so that the data gathered could be compared with the results of a similar survey conducted in the UK a decade ago. Professional networks and direct e-mails were used to distribute the survey electronically to potential respondents who were actively involved in PM in the three countries. A total of 150 responses are used in the analysis, 50 from each country.

Findings - The results show that there are many areas where the experiences, practices and views are similar across all three countries and are comparable to the earlier UK survey. However, as is often the case, it is perhaps the differences that are of most interest and these are commented upon throughout the paper.

Originality/value - This paper sheds light on current practice across three countries and presents a useful historical perspective on PM trends in practice and rates of credentialization of those surveyed. It also provides useful quantitative results that can be used to more broadly speculate and make sense of other qualitative studies.
\end{abstract}

Keywords Australia, Canada, United Kingdom, Project management

Paper type Research paper

\section{Introduction}

A paper published in 2002 (White and Fortune, 2002) set out the findings of a survey designed to: capture the "real world" experiences of people active in project management (PM) in the UK; determine the extent to which those involved in the management of projects actually made use of the methods and techniques that were available; and discover how effective the methods and techniques used were felt to be. This paper reports the results of a similar survey conducted during 2009 and looks at some of the differences between the two sets of findings. In addition, the sampling frame has been extended to cover Australia, Canada and the UK so that an international comparison

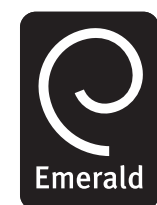

International Journal of Managing Projects in Business Vol. 4 No. 4, 2011 pp. $553-572$

(C) Emerald Group Publishing Limited $1753-8378$ 
IJMPB

4,4

554 can be made between the views and practices of people active in PM in those three countries. These three particular countries have been selected because they are English-speaking and comparable in terms of level of development, educational standards and international reach and though they are geographically very distant from each other they share many cultural similarities.

Although many survey findings relating to PM practice have been published over the last few years they have tended to focus on particular aspects of PM such as earned value management as a project performance evaluation technique (Bower and Finegan, 2009) or the use of PM information systems (Raymond and Bergeron, 2008) or on specific sectors such as construction (Liu and Low, 2011; Mojahed and Aghazadeh, 2008). This survey looks at a range of aspects and is not confined to one sector.

\section{Methodology}

A questionnaire comprising 24 questions with a mixture of yes/no, Likert-scale, multiple choice and open questions was developed. It explored the following areas:

- information about the respondent and the project upon which the replies were based;

- the criteria used for judging project outcomes;

- side-effects arising from projects;

- factors felt to be critical to project outcomes;

- methods, tools and techniques used; and

- the limitations or drawbacks of the methods, tools and techniques used.

Professional networks and direct e-mails were used to distribute the survey to potential respondents who were actively involved in PM in the three countries. Clearly, it is not possible to claim that the samples were randomly selected but the main concern was to attract responses from those who were active in PM and regarded themselves as "professionals" in this regard. A link to a URL where the questionnaire could be completed was provided and recipients were asked to base their responses on their most recently concluded project even if that project had been curtailed or abandoned. A hard copy of the survey was also available and was mailed upon request. Any information generated by the transmission process that would allow respondents to be identified was discarded upon receipt; all responses have been treated as anonymous.

It was decided in advance that 50 responses from each of the three countries would be used in the data analysis and that attempts to obtain responses would continue until 50 responses from each country that were comparable in terms of scale and type of project to the responses to the original survey had been obtained. This process took approximately three months.

\section{Analysis of data and discussion of results}

The following section sets out the main findings of the survey for each of the three countries and as a whole. For the early questions that deal with the respondents and their projects the data from the original survey has been included to demonstrate the extent to which the samples are comparable with each other and with the original survey. 


\subsection{The respondents and their projects}

Table I shows the results from the first set of questions for the separate countries and the original survey. It covers:

- the type of project such as whether it was construction, defence, information technology, reorganisation, or the like;

- whether the project on which the answers were based was carried out for an external client or within the respondent's own organisation;

- the industry sector in which the project was based;

- the size of the organisation where the project was undertaken;

- the number of people directly involved in the project;

- the part played in the project by the respondent and whether he or she regarded him or herself as the main decision maker; and

- the duration of the project.

Table I reveals that the survey samples are indeed comparable in terms of scale and type of project. The mode number of people directly involved in a project, including suppliers, where applicable, was 15 in the later survey compared with ten in the earlier survey but that is because three Australian, one Canadian and one UK projects were reported as involving extremely high numbers of people. The mode duration was a lot longer than in the earlier survey - 36 months as compared to six months - but the proportions lasting between six and 12 months are almost identical (38 percent compared with 37 percent).

There is no doubt that the role of project manager has become much more professionalised in recent years. (Morris et al. (2006, p. 711) described PM as a "semi-profession" or "commercialized profession") Sauer and Cuthbertson (2003, p. 17) characterise the pre-professional approach thus:

When a new project manager is required, all too often the selection process descends to being a matter of the next person to walk down the corridor.

To a large extent, the increase in professionalization has been brought about through growth in membership of professional organisations. For example, the Project Management Institute, which began in 1969 had approximately 1,000 members in 1974, 4,000 in 1983 (Wideman, 2001). By June 2010, it had around half a million members in 185 countries including over 381,000 certified project managers. When Sauer and Cuthbertson (2003) conducted a very large survey of Computer Weekly readers in late 2002 one of their questions was how well-equipped IT project managers were in 2002 compared with five years earlier. The results showed that there was a perception of significant improvement with 53 percent saying better or much better. Questions about the academic and professional qualifications of the respondents and the professional organisations to which they belong were included in the recent survey in order to explore this further. The responses are shown in Table II. All respondents except one from Canada indicated their highest level of academic qualification but a total of 31 respondents failed to reply to the question "please give details of any professional qualifications held".

Because one of the ways of reaching respondents was via professional networks it would not be prudent to attribute meaning to the difference in levels of membership
Current practice in project management

555 


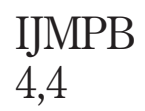

\section{6}

Project type

Australia

Canada

UK

All respondents Original survey

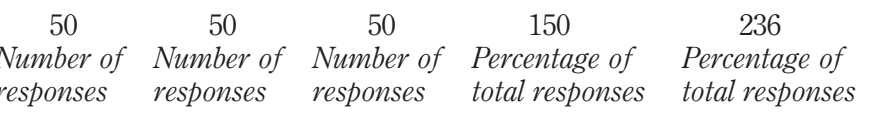

responses responses responses total responses

Percentage of

5

Construction

Defence

Engineering

Feasibility studies

Information technology

Other

Reorganisation

Research and

development

Software development

Staff development/

training

Project carried out for

A client

Within own organisation

Industry sector

Construction

Defence

Education and training

Finance and insurance

Health care and social

assistance

Information media and

telecommunications

Manufacturing

Mining, quarrying, and

oil and gas extraction

Other

Public administration

Utilities

Wholesale and retail

trade

\section{3}

\section{4}

$\begin{array}{ll}4 & 6 \\ 1 & 4\end{array}$

$\begin{array}{rr}1 & 4 \\ 17 & 13\end{array}$

3

$$
8
$$

2$$
\begin{aligned}
& 2 \\
& 4
\end{aligned}
$$

$$
3
$$

32

18

50

$5 \quad 3$

3

2
6

$$
0
$$

6

$$
5
$$

$\begin{array}{rrr}6 & 13 & \\ 4 & 9 & 11 \\ 10 & 3 & \\ 3 & 5\end{array}$

Number of employees within organisation where project carried out

Fewer than ten

$10-99$

$100-499$

$500-999$

1,000 or more

Number of people directly involved in the project including suppliers

Fewer than ten

10-99

$100-499$

500-999

1,000 or more

Table I.

The respondents and their projects
Respondent's part in project

Consultant

$\begin{array}{lr}4 & 0 \\ 3 & 11 \\ 7 & \end{array}$

$7-11$

$12 \quad 14$

$24 \quad 21$

8
29
6

6

4

3

6

7
31
10
1
1

31

10

1

4

6
10.00

4.00

6.67

4.00

28.67

10.00

21.33

3.33

7.33

4.67

52.67

47.33

5.33

4.00

6.00

11.33

5.33

12.67

5.33

12.67

16.00

14.00

6.00

1.33

5.33

6.00

17.33

24.00

47.33

12.00

62.67

16.00

6.00

3.33

10.67
2.12

2.97

8.05

2.12

25.42

12.71

18.64

11.86

11.02

5.08

37.29

62.71

0.42

3.81

2.54

19.92

4.66

3.39

8.47

4.66

24.15

19.92

3.39

4.66

0.42

2.97

14.83

13.98

67.80

44.44

47.50

6.39

0.83

0.83

6.36

(continued) 


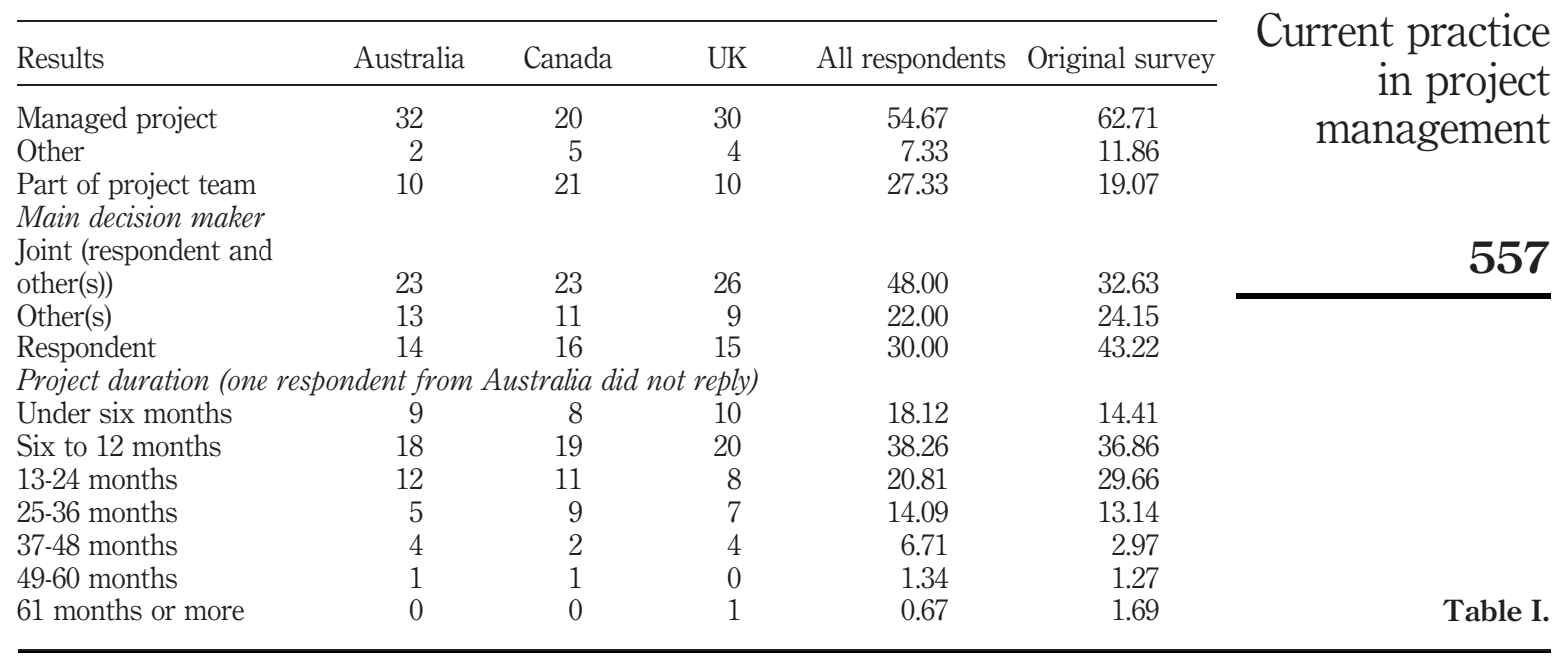

of professional bodies across the three countries or to see the data as representative of the levels of membership in any one country but it is worth noting that there are differences between the countries even where the same institutions and qualifications are available within them. One example is the Project Management Institute's Project Management Professional (PMP) qualification. It is not surprising that PRINCE2 qualifications are more prevalent in the UK given the approach originated there but it is interesting that whilst it is making inroads into Australia it has not migrated to Canada and nor does it have any direct equivalent there.

\subsection{Success rates and criteria used for judging project outcomes}

As stated above, recipients were asked to base their responses on their most recently concluded project even if that project had been curtailed or abandoned. In considering success rates it is relevant to note the last phase completed on the project. This is shown in Table III alongside the phase at which the respondent entered the project. Overall, 68 percent of projects ran through to completion.

Respondents were also asked to judge their projects' success on a scale of 1 to 7 where 1 represented complete success and 7 represented complete failure. The results are shown in Figure 1. The country where most success was reported was the UK with a total of 47 projects being rated 1, 2 or 3 . For Australia 38 projects were put in these three categories whilst for Canada the number was 40. Overall, 16 percent of projects were judged to be a complete success and only one project (a Canadian project) was regarded as a complete failure. The comparable figure to the 16 percent judged a complete success that was obtained in the original UK survey was 41 percent. It was remarked at the time that a success rate of 41 percent was far higher than typical success rates reported in the literature. A survey of IT projects in 400 organisations conducted by the Standish Group in 2009 found that 32 percent were considered successful and 24 percent were considered failures. The remaining 44 percent were “considered challenged” (Standish Group, 2009). 


\section{IJMPB \\ 4,4}

\section{8}

Table II.

Responses given to questions about qualifications and membership of professional organisations

\begin{tabular}{|c|c|c|c|c|}
\hline & Australia & Canada & UK & All respondents \\
\hline \multicolumn{5}{|l|}{ Professional qualifications } \\
\hline No response given & 7 & 12 & 12 & 31 \\
\hline One qualification given & 25 & 32 & 22 & 79 \\
\hline Two qualifications given & 7 & 5 & 7 & 19 \\
\hline Three qualifications given & 2 & 1 & 8 & 11 \\
\hline Four qualifications given & 7 & 0 & 0 & 7 \\
\hline Five qualifications given & 2 & 0 & 1 & 3 \\
\hline Total & 50 & 50 & 50 & 150 \\
\hline \multicolumn{5}{|l|}{ Membership of professional organisations } \\
\hline No response given & 6 & 16 & 18 & 40 \\
\hline Membership of one organisation & 25 & 24 & 15 & 64 \\
\hline Membership of two organisations & 11 & 6 & 10 & 27 \\
\hline Membership of three organisations & 3 & 2 & 2 & 7 \\
\hline Membership of four organisations & 5 & 1 & 4 & 10 \\
\hline Membership of five organisations & 0 & 1 & 1 & 2 \\
\hline Total & 50 & 50 & 50 & 150 \\
\hline \multicolumn{5}{|l|}{ Respondent's highest academic qualification } \\
\hline Bachelor degree & 14 & 11 & 18 & 43 \\
\hline Certificate & 2 & 2 & 2 & 6 \\
\hline Diploma & 6 & 3 & 5 & 14 \\
\hline Doctorate & 2 & 2 & 2 & 6 \\
\hline Masters degree & 19 & 21 & 14 & 54 \\
\hline None & 0 & 0 & 3 & 3 \\
\hline Other & 1 & 4 & 1 & 6 \\
\hline Postgraduate certificate & 2 & 2 & 0 & 4 \\
\hline Postgraduate diploma & 4 & 4 & 5 & 13 \\
\hline Total & 50 & 49 & 50 & 149 \\
\hline \multicolumn{5}{|l|}{ Top five professional qualifications held by respondents } \\
\hline Project management professional (PMP) & 13 & 17 & 3 & 33 \\
\hline PRINCE2 - practitioner & 7 & 0 & 21 & 28 \\
\hline Master of business administration & 5 & 5 & 4 & 14 \\
\hline Master of project management & 5 & 5 & 1 & 11 \\
\hline Diploma in project management & 4 & 0 & 1 & 5 \\
\hline \multicolumn{5}{|c|}{ Top five professional organisations to which respondents belonged } \\
\hline Project Management Institute & 25 & 21 & 6 & 52 \\
\hline Australian Institute of Project Management (AIPM) & 20 & 0 & 0 & 20 \\
\hline Association for Project Management (APM) & 1 & 0 & 12 & 13 \\
\hline British Computer Society & 1 & 1 & 9 & 11 \\
\hline Australian Computer Society (ACS) & 3 & 0 & 1 & 4 \\
\hline
\end{tabular}

Respondents were also asked to provide and to rank in order of importance the success criteria they had used to make the judgement about their own project's level of success on the scale of 1-7. In order to determine the criteria regarded as most important a criteria was given a score of 3 if it was ranked first, 2 if it was ranked second and 1 if it was ranked third. The total scores for each criteria are displayed in Table IV where it can be seen that the three highest scoring criteria are "meets client's requirements", "completed within schedule" and "completed within budget". This selection and placing is the same as in the original survey but there are interesting differences between the original and the new survey where the next tranche of criteria 


\begin{tabular}{|c|c|c|c|c|c|}
\hline $\begin{array}{l}\text { Phase respondent } \\
\text { entered }\end{array}$ & $\begin{array}{l}\text { Australia } \\
(n=50)\end{array}$ & $\begin{array}{l}\text { Canada } \\
(n=50)\end{array}$ & $\begin{array}{c}U K \\
(n=50)\end{array}$ & $\begin{array}{l}\text { All respondents } \\
\quad(n=150)\end{array}$ & in project \\
\hline Initiation phase & 24 & 31 & 34 & 89 & manage \\
\hline Planning phase & 19 & 13 & 12 & 44 & 11101108 \\
\hline Execution phase & 4 & 6 & 4 & 14 & \\
\hline Closeout phase & 3 & 0 & 0 & 3 & \\
\hline Last phase completed & $\begin{array}{l}\text { Australia } \\
(n=49)\end{array}$ & $\begin{array}{l}\text { Canada } \\
(n=49)\end{array}$ & $\begin{array}{c}U K \\
(n=48)\end{array}$ & $\begin{array}{c}\text { All respondents } \\
(n=146)\end{array}$ & \\
\hline Initiation phase & 0 & 1 & 1 & 2 & Table III. \\
\hline Planning phase & 4 & 7 & 2 & 13 & Phase respondent entered \\
\hline Execution phase & 10 & 9 & 12 & 31 & project and last $\mathrm{pl}$ \\
\hline Closeout phase & 35 & 32 & 33 & 100 & completed on $\mathrm{p}$ \\
\hline
\end{tabular}

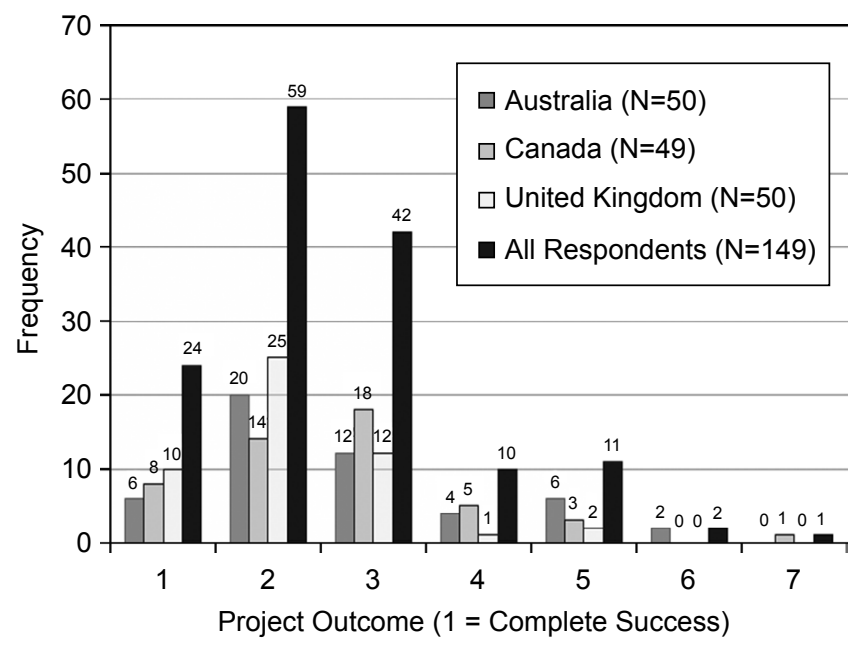

Figure 1. Project outcome

are concerned. "Meets quality and/or safety standards" was seventh in the original survey but had moved to fourth place this time. The criteria placed fourth in the original survey, "meets organizational benefits", has fallen to sixth place and achieved a total score of only a little over half that achieved by "meets quality/safety standards". Many of the surveys that have been published recently (Lierni and Ribiere, 2008; Pereira et al., 2008; Raymond and Bergeron, 2008; Rosacker and Olson, 2008) provided success criteria for their respondents to use in their judgements of their own projects' success but one that allowed respondents to select their own (Murphy and Ledwith, 2007) found "meeting required quality standards" was the most important success criteria used by respondents with "meeting specification" second.

Another study of success criteria is reported by Thomas and Fernandez (2008). They investigated success criteria in 36 Australian companies operating in three industry sectors: finance and insurance; electricity gas and water supply; and mining. They interviewed a chief information officer or program office manager or equivalent and a project manager in each of the companies and elicited the criteria they used to judge the success of their projects. Thomas and Fernandez do not report the importance 


\section{IJMPB 4,4}

\section{0}

Table IV.

Criteria used for judging project success

\begin{tabular}{lcrrr}
\hline Criteria & Australia & Canada & UK & Grand total \\
\hline Meets client's requirements & 96 & 81 & 102 & 279 \\
Completed within schedule & 68 & 62 & 48 & 178 \\
Completed within budget & 43 & 38 & 34 & 115 \\
Meets quality and/or safety standards & 28 & 28 & 14 & 70 \\
Yields business and other benefits & 23 & 8 & 23 & 54 \\
$\begin{array}{l}\text { Meets organizational objectives } \\
\text { Causes minimal business disruptions }\end{array}$ & 14 & 18 & 5 & 37 \\
$\begin{array}{l}\text { Is capable of adapting to internal and/or external } \\
\text { changing needs }\end{array}$ & 6 & 14 & 9 & 29 \\
$\begin{array}{l}\text { Delivers the best value possible } \\
\text { Provides strategic or operation learning for the }\end{array}$ & 1 & 7 & 12 & 25 \\
organisation & 3 & 9 & 0 & 10 \\
$\begin{array}{l}\text { Facilitates leading the organisation into future } \\
\text { business/direction }\end{array}$ & 0 & 0 & 4 & 7 \\
$\begin{array}{l}\text { Delivers return on investment } \\
\text { Makes only limited use of contingency funds }\end{array}$ & 4 & 0 & 5 & 5 \\
Delivers enhanced reputation for the organisation & 0 & 0 & 2 & 4 \\
\end{tabular}

placed on particular criteria but they do say that companies used between two and 11 criteria with a average of 5 , there was a focus on "on-time" and "on-budget", and that 26 companies (72 percent of their sample) considered company success criteria such as "delivery of benefits". The equivalent figures for the number of criteria used for the survey being reported here are: Australia, two to seven criteria with an average of 3 ; Canada, one to eight criteria with an average of 4; and UK, one to eight criteria with an average of 8. In the earlier UK survey one to six criteria were used with an average of 3.

\subsection{Side-effects}

The emergence of unintended consequences or side-effects was another area explored by the survey. A total of 58 respondents (39 percent) reported that their project gave rise to side-effects. Their descriptions of these side-effects (10 respondents described two), grouped into desirable side-effects and undesirable side-effects, are displayed in Table V. As the table shows, the occurrence of side-effects was spread unevenly across the countries with Canadian respondents reporting substantially fewer desirable side-effects and Australian respondents reporting substantially more undesirable side-effects. In the original survey 46 percent of respondents reported side-effects and nearly 70 percent of those could be attributed either directly or indirectly to lack of awareness of the environment. In reporting the 2002 survey, White and Fortune postulated that this could have been because many of the tools and techniques the respondents used were poor at modelling "real world" problems or that insufficient account was taken of project boundaries and environments but in the more recent survey this link between side-effects and lack of awareness of the environment did not emerge.

\subsection{Factors felt to be critical to the project's outcome}

The next section of the questionnaire drew on the original survey and a published review of 63 publications that focus on critical success factors (Fortune and White, 2006). This review found 27 different factors are cited across the 63 publications and the three most cited factors are: the importance of a project receiving support from 


\begin{tabular}{|c|c|c|c|c|c|}
\hline & Australia & Canada & UK & All respondents & in project \\
\hline \multicolumn{5}{|l|}{ Desirable side-effects } & management \\
\hline Increased business/sales/opportunities & 11 & 2 & 8 & 21 & \\
\hline New understanding/knowledge gained & 6 & 2 & 9 & 17 & \\
\hline Improved business/staff relations & 0 & 1 & 1 & 2 & \\
\hline Total & 17 & 5 & 18 & 40 & 561 \\
\hline $\begin{array}{l}\text { Undesirable side-effects } \\
\text { Problems with staff/client/contractors/suppliers }\end{array}$ & 4 & 3 & 1 & 8 & \\
\hline Undesirable organisational impact/conflict & 5 & 0 & 1 & 6 & \\
\hline Lack of awareness of the environment & 2 & 1 & 1 & 4 & \\
\hline Technical limitations came to light & 4 & 0 & 0 & 4 & \\
\hline Underestimation of cost/time & 3 & 0 & 0 & 3 & Table V. \\
\hline Changes to goal/objectives & 0 & 2 & 0 & 2 & Side-effects - \\
\hline Conflicting priorities & 0 & 0 & 1 & 1 & descriptions and \\
\hline Total & 18 & 6 & 4 & 28 & frequency of mention \\
\hline
\end{tabular}

senior management; having clear and realistic objectives; and producing an efficient plan. However, it also found that there is only limited agreement among authors on the factors that influence project success; although 51 of the 63 publications include at least one of the three most cited factors only 11 cite all three.

Respondents were asked to indicate and rank the three factors they believed to be most critical to their projects' outcomes. The re-coded responses $(1=3,2=2,3=1$ and factor not stated $=0$ ) are displayed in Table VI. Two factors, clear goals/objectives and support from senior management, stand out from the rest in all three countries, with realistic schedule in third place. This is a very good fit with the findings of the review and the original survey where the top four were:

(1) clear goals/objectives;

(2) realistic schedule;

(3) support from senior management; and

(4) adequate funds/resources.

A factor that has risen in the rankings is effective team building/motivation. This was 13th in the original survey and is overall sixth in Table VI with no dramatic variations in the results from the individual countries.

End-user commitment is the only factor to have fallen substantially in the rankings when comparing the two surveys. It was ranked as the fifth most important factor in the original survey with 23 (of 236) respondents ranking it first, 18 second and 22 third. It is in 12th place in terms of overall responses in Table VI; in Australia one respondent ranked it first and another ranked it third, in Canada one respondent ranked it first, two ranked it second and two-third but in the UK two respondents ranked it first, three respondents ranked it second and six ranked it third. One explanation for these differences could be the type of projects being considered in the different surveys but that is unlikely to be the case. As Khazanchi and Reich (2008) say in the context of looking at IT project success, "failure to manage end-user expectations' is enormously important for all types of [IT] projects", and if the incidences of information technology 


\section{IJMPB}

4,4

562

Factors

Australia Canada UK All responses

Clear goals/objectives

Support from senior management

Realistic schedule

Adequate funds/resources

Clear communication channels

Effective team building/motivation

Flexible approach to change

Effective leadership/conflict resolution

Taking account of external influences

Effective management of risk

Taking account of past experience

End-user commitment

Recognising complexity

Contextual awareness

Provision of planning and control systems

Effective monitoring and feedback

Considering multiple views of a project

Other factor(s)

Appreciating the effect of human error

Stable/skilled/integrated project team

Taking account of regional/international cultural differences

Table VI.

Factors critical to the project's outcome
Effective selection/use of technology

Training provision

Effective stakeholder engagement/management/sponsorship

Wide/well-considered/unchanged scope

$\begin{array}{rrrr}61 & 39 & 47 & 147 \\ 36 & 44 & 51 & 131 \\ 23 & 29 & 22 & 74 \\ 29 & 28 & 12 & 69 \\ 18 & 14 & 16 & 48 \\ 16 & 13 & 15 & 44 \\ 9 & 17 & 17 & 43 \\ 15 & 14 & 12 & 41 \\ 11 & 7 & 23 & 41 \\ 14 & 9 & 14 & 37 \\ 18 & 4 & 14 & 36 \\ 4 & 9 & 18 & 31 \\ 16 & 7 & 6 & 29 \\ 7 & 8 & 13 & 28 \\ 9 & 9 & 5 & 23 \\ 5 & 3 & 5 & 13 \\ 1 & 9 & 2 & 12 \\ 0 & 6 & 0 & 6 \\ 5 & 0 & 0 & 5 \\ 0 & 3 & 2 & 5 \\ 0 & 4 & 0 & 4 \\ 0 & 2 & 0 & 2 \\ 1 & 1 & 0 & 2 \\ 1 & 0 & 0 & 1 \\ 1 & 0 & 0 & 1\end{array}$

and software development projects are combined in each survey they account for the same proportion of projects (36 percent).

\subsection{Methods, methodologies, tools and techniques}

The section on methods, methodologies, tools and techniques presented respondents with a list of options grouped as follows:

- PM methodologies (four options);

- PM software (three options);

- PM tools (eight options);

- decision-making techniques (five options);

- risk assessment tools (seven options); and

- information communication technology (ICT) support tools (six options).

Respondents were asked to indicate which had been used in the project being considered and were encouraged to add to the list of options if necessary. The options presented in the lists were chosen for inclusion because it was known they were in widespread use in one or more of the three countries. Some of them (for example, projects in controlled environments (PRINCE and PRINCE2) and Gantt bar charts) were included in the original survey but others, including each of the ICT support tools had not. "Project management software" was included as just one of the set of PM tools 
in the original survey but on this occasion it was provided as a separate section due to its increased availability. Table VII shows the responses. The methods, methodologies, tools and techniques that were provided in the lists of options on the questionnaire are shown in quotes. In Australia the maximum number of methods, methodologies, tools or techniques used by a single respondent was 33 , the mode was 8 and the mean was 11 . For Canada the corresponding figures were 41, 9 and 10 and for the UK they were 26, 6 and 10. In the original UK only survey the maximum figure was 23 but the mode was only 3 and the mean was 5 .

Across the three countries the most uneven usage was seen in the case of PRINCE2. This mirrors the data on PRINCE2 qualifications to which reference was made earlier in this paper. It was used very widely in the UK, to a much more limited extent in Australia and not at all in Canada. "Methodology developed in house" appears to substitute for it there. Indeed, if the figures for PRINCE2 and "methodology developed in house" are added together for each country the variation in the totals is not very great. When the data for the UK is compared with the earlier survey there has been a substantial increase in the use of PRINCE2 and a corresponding reduction in "in house". The two other changes that are noticeable when comparing the original survey with the later survey are an increase in the use of work breakdown structure (WBS) and a reduction in the use of structured systems analysis and design methodology (SSADM). Indeed, use in the UK of SSADM was entirely absent.

It is as interesting to note how many respondents did not use methods, methodologies, tools or techniques. This data are shown in Table VIII. The lowest amounts of usage overall was found in three separate responses. An Australian respondent just used Gantt charts, one UK respondent just used PRINCE and another from the UK just used PRINCE2.

A useful comparator for the survey data reported here is the work of Besner and Hobbs (2008). In a large-scale survey of PM practitioners (nationality not specified) Besner and Hobbs presented respondents with a list of 70 tools the authors regarded as "the tools and techniques that are identified with the practice of project management" and asked them to identify the ones they used. The four most used tools in their survey were progress report, kick-off meeting, PM software for task scheduling and Gantt chart. The first two of these do not appear in Table VII though perhaps they were not regarded as PM-specific tools by respondents. Use of WBS was not as great in the Besner and Hobbs survey where it appeared ninth.

3.6 Limitations and drawbacks of the methods, methodologies, tools and techniques used The percentages of respondents who said they had encountered limitations or drawbacks with the methods, methodologies, tools or techniques they had used were 66, 52 and 18 percent for the Australian, Canadian and UK samples, respectively. The overall figure was 45 percent which is an increase on the 42 percent reporting limitations or drawbacks in the original survey. Many respondents named more than one method, tool or technique with which they had encountered limitations or drawbacks. Table IX shows the methods and tools with the highest frequency of reported limitations as a percentage of their reported use. It should be noted that if the figures for Groupware and Integrated Groupware are taken together, they account for 28 percent (20 respondents).

In Table X the methods, tools and techniques have been cross-tabulated with the descriptions of the limitations where these were provided. A total of 19 respondents

\section{Current practice in project management}

563 


\title{
IJMPB
}

4,4

564

\begin{tabular}{ccccc}
\hline $\begin{array}{c}\text { Australia } \\
\text { count }\end{array}$ & $\begin{array}{c}\text { Canada } \\
\text { count }\end{array}$ & $\begin{array}{c}\text { UK } \\
\text { count }\end{array}$ & $\begin{array}{c}\text { All } \\
\text { count }\end{array}$ \\
\hline
\end{tabular}

Project management methodologies

"Methodology developed 'in house"

"Projects in controlled environments 2

(PRINCE2)"

Other project management methodologies

PMBOK

Agile

"Projects in controlled environments (PRINCE)"

Managing successful programmes

Rationale unified process

"Structured systems analysis and design

methodology (SSADM)"

Wysocki's adaptive project framework (APF)

Total

Project management software

"Microsoft project"

Other project management software

"Primavera"

MS excel

Project management software developed

in house

Visio

Open plan professional

SAP

“@task”

CA clarity

Project place

Powerpoint

Oracle

Total

Project management tools

"GANTT bar charts"

"Work breakdown structure (WBS)"

$\begin{array}{llll}37 & 41 & 22 & 100\end{array}$

8

6

6

0

1

0

0

2
0

0
60

54

0

28

36

2

$6 \quad 14$

$\begin{array}{ll}1 & 11\end{array}$

$\begin{array}{lr}1 & 11 \\ 2 & 6\end{array}$

$\begin{array}{ll}2 & 4\end{array}$

$3 \quad 3$

12

"Lessons learnt (also known as project reviews/ project audits)"

"Critical path method (CPM)"

$\begin{array}{rrrr}35 & 27 & 32 & 94 \\ 14 & 11 & 3 & 28 \\ 12 & 12 & 3 & 27 \\ 5 & 4 & 4 & 13\end{array}$

"Strengths weaknesses, opportunities and threats (SWOT)"

"Cash flow analysis (CFA)"

4

"Programme evaluation and review technique (PERT)"

Other project management tools

"Monte Carlo"

In house project management tools

Table VII.

Earned value management

Delphi method

Agile board

Project goals charter

Total methods, methodologies,
185 extent of use

\author{
(1)
}

10

$\begin{array}{rr}2 & 9 \\ 0 & 7 \\ 0 & 3 \\ 2 & 3 \\ 1 & 2 \\ 0 & 2 \\ 2 & 2 \\ 1 & 2 \\ 0 & 1 \\ 50 & 193 \\ & \\ 38 & 103 \\ 26 & 101 \\ & \\ 31 & 91 \\ 18 & 63\end{array}$

$\begin{array}{lll}29 & 38 & 103 \\ 35 & 26 & 101 \\ & & \\ 28 & 31 & 91 \\ 19 & 18 & 63\end{array}$

$\begin{array}{lrl}14 & 18 & 40 \\ 12 & 6 & 31\end{array}$

$\begin{array}{rrr}8 & 9 & 27 \\ 11 & 5 & 26 \\ 4 & 2 & 9 \\ 0 & 4 & 8 \\ 3 & 1 & 5 \\ 0 & 2 & 4 \\ 1 & 1 & 2 \\ 0 & 2 & 2 \\ 164 & 163 & 512 \\ & & \text { (continued) }\end{array}$




\begin{tabular}{|c|c|c|c|c|c|}
\hline & $\begin{array}{l}\text { Australia } \\
\text { count }\end{array}$ & $\begin{array}{l}\text { Canada } \\
\text { count }\end{array}$ & $\begin{array}{l}\text { UK } \\
\text { count }\end{array}$ & $\begin{array}{c}\text { All } \\
\text { count }\end{array}$ & \multirow{2}{*}{$\begin{array}{l}\text { in project } \\
\text { management }\end{array}$} \\
\hline \multicolumn{5}{|l|}{ Decision-making techniques } & \\
\hline "Cost-benefit analysis (CBA)" & 27 & 23 & 26 & 76 & \\
\hline "Decision analysis (DA)" & 10 & 11 & 10 & 31 & \\
\hline "Sensitivity analysis (SA)" & 11 & 8 & 8 & 27 & 565 \\
\hline "Expressed preferences" & 6 & 9 & 7 & 22 & 56 \\
\hline "Implied/revealed preferences" & 5 & 6 & 2 & 13 & \\
\hline Other decision-making techniques & 5 & 4 & 2 & 11 & \\
\hline In house decision-making techniques & 1 & 4 & 2 & 7 & \\
\hline Decision trees & 1 & 1 & 0 & 2 & \\
\hline Stakeholder analysis & 1 & 0 & 1 & 2 & \\
\hline Total & 67 & 66 & 58 & 191 & \\
\hline \multicolumn{6}{|l|}{ Risk assessment tools } \\
\hline "Probability analysis" & 16 & 14 & 16 & 46 & \\
\hline "Life-cycle cost analysis (LCC)" & 11 & 5 & 11 & 27 & \\
\hline "Failure modes and effect analysis (FMEA)" & 8 & 3 & 5 & 16 & \\
\hline "Reliability analysis" & 6 & 5 & 5 & 16 & \\
\hline "Hazard and operability studies (HAZOP)" & 4 & 8 & 3 & 15 & \\
\hline In house risk assessment tools & 9 & 0 & 4 & 13 & \\
\hline "Fault tree analysis (FTA)" & 5 & 3 & 3 & 11 & \\
\hline Other risk assessment tools & 4 & 6 & 1 & 11 & \\
\hline "Hazard analysis (HAZAN)" & 5 & 3 & 2 & 10 & \\
\hline Risk analysis using ASNZS 4360_2004 & 5 & 0 & 0 & 5 & \\
\hline Risk register & 1 & 0 & 4 & 5 & \\
\hline Delphi method & 2 & 0 & 0 & 2 & \\
\hline Risk assessment & 0 & 2 & 0 & 2 & \\
\hline Total & 76 & 49 & 54 & 179 & \\
\hline \multicolumn{6}{|l|}{ Information communication technology support tools } \\
\hline tools, shared access to web portals, etc.)" & 24 & 24 & 29 & 77 & \\
\hline "Groupware (e-mail only)" & 20 & 29 & 20 & 69 & \\
\hline "Video conferencing" & 11 & 16 & 24 & 51 & \\
\hline "Voice over internet protocol" & 11 & 11 & 9 & 31 & \\
\hline "Virtual environments" & 9 & 9 & 5 & 23 & \\
\hline \multicolumn{6}{|l|}{ Other information communication technology } \\
\hline support tools & 5 & 8 & 4 & 17 & \\
\hline In house communication and reporting system & 5 & 4 & 6 & 15 & \\
\hline "Communities of practice enabling tools" & 5 & 3 & 3 & 11 & \\
\hline Total & 90 & 104 & 100 & 294 & \\
\hline \multirow[t]{2}{*}{ Grand total } & 557 & 501 & 491 & 1,549 & Table VII. \\
\hline & Australia & Canada & UK & All responses & \multirow{8}{*}{$\begin{array}{r}\text { Table VIII. } \\
\text { Numbers not using } \\
\text { project management } \\
\text { methods, methodologies, } \\
\text { tools and techniques }\end{array}$} \\
\hline Did not use any project management methodologies & 5 & 3 & 4 & 12 & \\
\hline Did not use any project management software & 4 & 9 & 10 & 23 & \\
\hline Did not use any project management tools & 1 & 3 & 4 & 8 & \\
\hline Did not use decision-making techniques & 14 & 14 & 16 & 44 & \\
\hline & 10 & 25 & 20 & 55 & \\
\hline \multirow{2}{*}{$\begin{array}{l}\text { Did not use any information communication } \\
\text { technology support tools }\end{array}$} & & & & & \\
\hline & 7 & 6 & 7 & 20 & \\
\hline
\end{tabular}




\section{IJMPB \\ 4,4}

\section{6}

Table IX.

Limitations reported

\begin{tabular}{|c|c|c|c|}
\hline Methods/tools with limitations & $\begin{array}{l}\text { Number of } \\
\text { respondents using } \\
\text { this method/tool }\end{array}$ & $\begin{array}{l}\text { Number of users } \\
\text { reporting } \\
\text { limitations }\end{array}$ & $\begin{array}{l}\text { Limitations as a } \\
\text { percentage of extent } \\
\text { of use }\end{array}$ \\
\hline
\end{tabular}

Other project management methodologies

Other project management software

Methodology developed "in house"

Groupware (e-mail only)

Work breakdown structure (WBS)

Integrated groupware (e-mail, collaborative tools, shared access to web portals, etc.)

$\begin{array}{rrr}14 & 8 & 57.14 \\ 28 & 11 & 39.29 \\ 100 & 27 & 27.00 \\ 69 & 12 & 17.39 \\ 101 & 11 & 10.89 \\ & & \\ 77 & 8 & 10.39\end{array}$

gave descriptions of the limitations to Groupware or Integrated Groupware. These included lack of training, security issues, unstable technology and problems with bandwidth. Examples of descriptions of limitations included as "other" in Table X include: "would have appreciated greater access to video conferencing"; "governance structures were too restrictive and choked the project process"; and "only one aspect of cost-benefit analysis (CBA) was evaluated".

Comparison of the data on limitations and drawbacks with its equivalent from the original survey is interesting. PM software topped the table in the original survey where it was the most mentioned method, methodology, tool or technique with limitations and had the highest frequency of limitations as a percentage of reported use. Of the approximately 20 percent of respondents who experienced problems with PM software in the original survey, half found the software "inadequate for complex projects". It is also worth noting that use of PRINCE and PRINCE2 was much lower in the original survey but they still came third in the equivalent of Table IX. It may be the case that the reduction in the extent to which limitations and drawbacks are perceived is due to better training as evidenced by the high number of respondents with qualifications in PRINCE2 (Table II).

\section{Conclusion}

This paper has reported the results of a survey conducted in Australia, Canada and the UK that attempted to capture the "real world" experiences of project managers and has compared the findings with a similar survey conducted in the UK a decade ago. Much of the data gathered showed a substantial level of similarity across the individual data sets from the three countries. However, there were also differences. One example is the extent to which PRINCE2 is used. As the discussion in Sections 3.1 and 3.5 shows, use of PRINCE2 was reported very frequently in the UK, less frequently in Australia and not at all in Canada. Another difference is the number of side-effects (desirable and undesirable) reported. The UK reported the most desirable side effects and the least undesirable side effects. In the original survey 46 percent of respondents reported side-effects.

When the results of the later survey are compared with the original UK survey the most striking differences concern the extent to which PM methodologies and tools are used. The percentage of respondents who did not use a methodology was 28 percent in the original survey compared with 8 percent in the later survey overall and 8 percent in the UK sample only. The average number of tools used per respondent in the original survey was 5.13 but overall in the recent survey this had risen to 10.37 (9.84 UK sample only). 


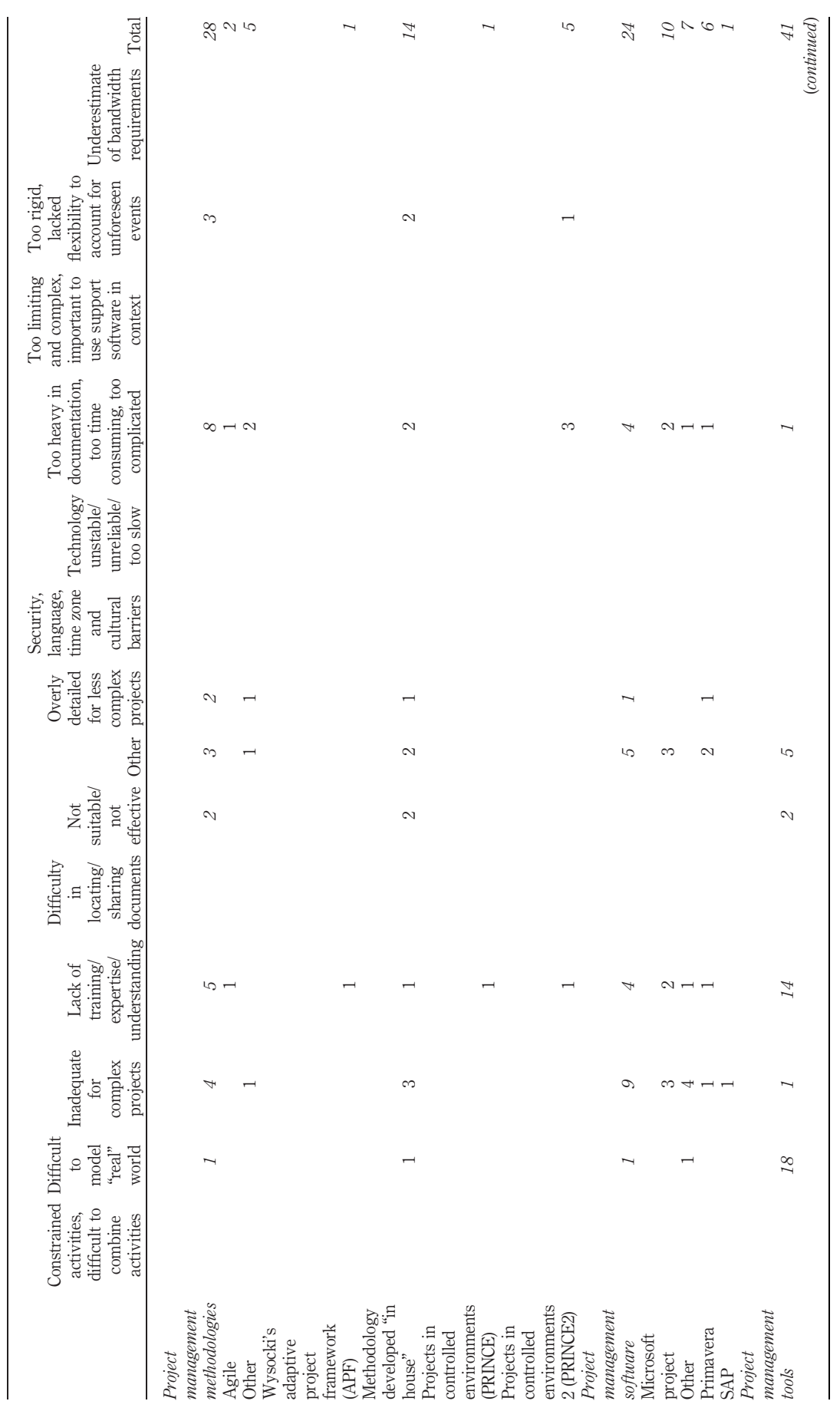

Current practice in project management

567

Table X.

Cross-tabulation of the methods, tools and techniques with limitations and the descriptions of the limitations 


\section{IJMPB \\ 4,4}

568

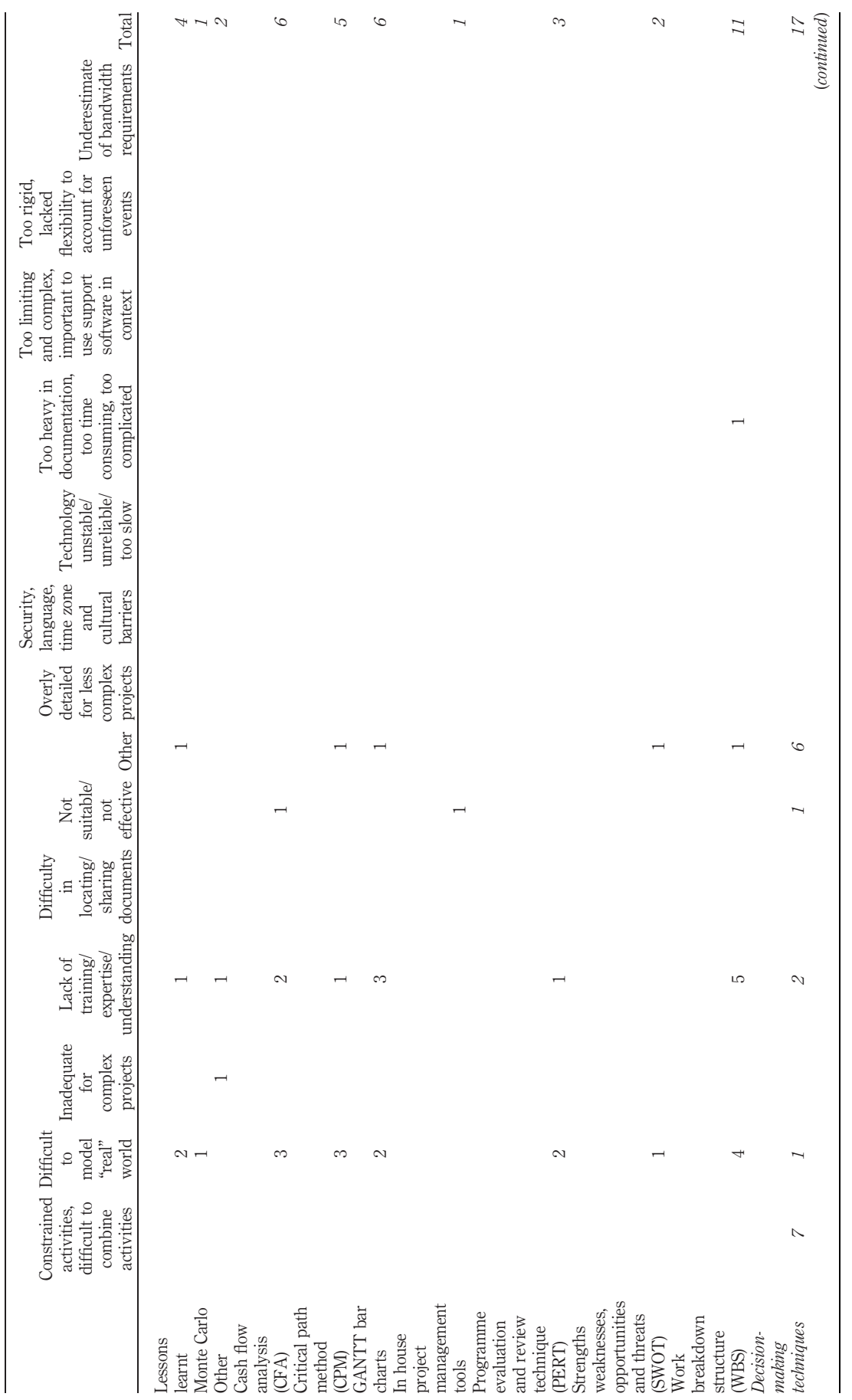

Table X. 


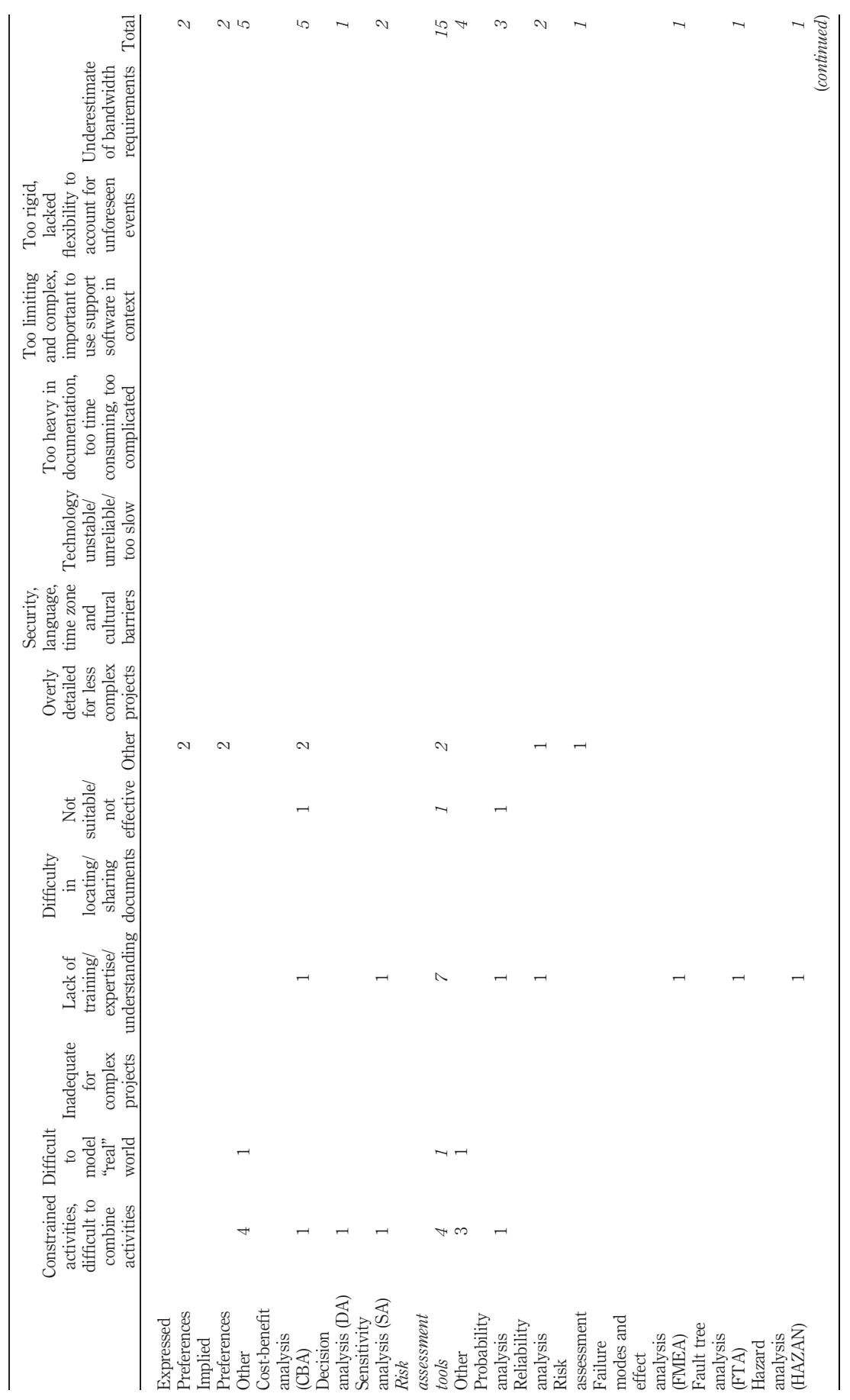

Current practice in project management

569

Table X. 

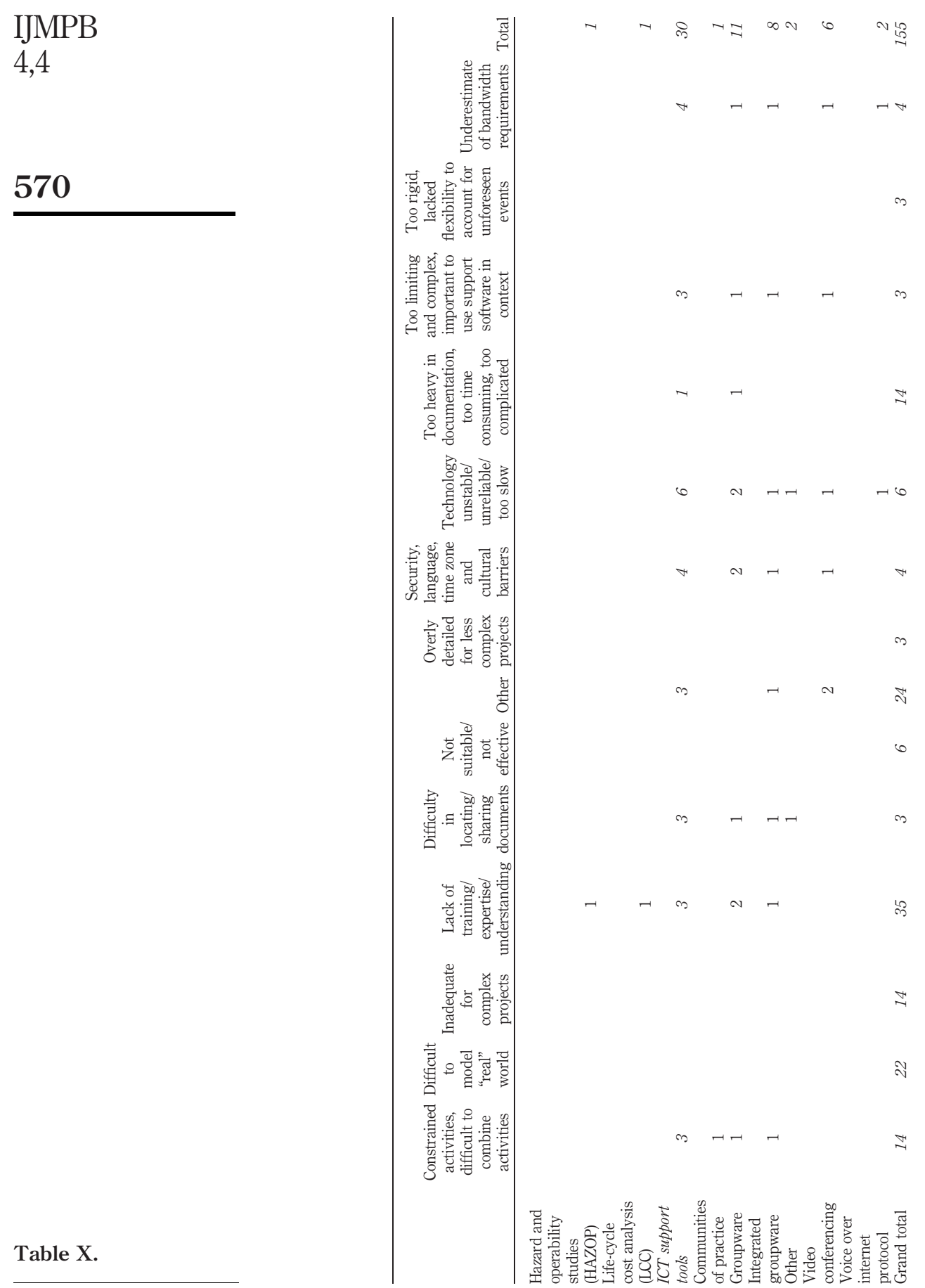

Table X. 
Within these overall figures it is worth noting the contribution made by risk assessment tools. Whilst the average number of risk assessment tools used per respondent was still small (1.19 overall, $1.08 \mathrm{UK}$ sample) it was remarkably higher than the figure of 0.16 that emerged from the earlier survey. Furthermore, the percentage of respondents who did not use any risk assessment tools had fallen from 65 to 37 percent overall and 40 percent, UK sample only. This supports Morris et al's impression (Morris et al., 2006) that project managers are becoming more "professional" in terms of use of tools and techniques.

Naturally this paper is subject to several caveats in relation to its generalizability. One is that it is only based upon 50 responses from each country (see Shehu and Akintoye (2010) for a discussion of the increasing difficulties of attracting large numbers of responses to surveys) and the intention was to shed light on current practice rather than generate statistically significant results. Second, the survey is highly UK-culturally centric with no USA or European-based practitioners being included (though of course respondents may have been educated and/or gained formative experience outside the UK, Canada and Australia). It should also be noted that this study has surveyed project managers who were already engaged in responding to a project brief rather than developing a project's purpose or aim or assessing its viability. Recent work that has emerged from the study of aid and disaster recovery projects (Ika et al., 2010; Steinfort, 2010; Steinfort and Walker, 2011) has stressed the importance of thorough front-end analysis of the purpose of the proposed project and of setting up effective monitoring and evaluation of benefits delivered rather than just relying on the use of tools and techniques geared towards project progress delivery. This front-end of project focus that has been shown in the literature cited above to be crucial in terms of "doing the right project" as opposed to "doing the project right" has not been explored in this survey.

However, as a partial longitudinal comparison with the early UK only survey published by White and Fortune (2002), this does present a useful historical perspective on PM trends in practice and rates of credentialization of those surveyed. The research presented should provide useful quantitative results that can be used to more broadly speculate and make sense of qualitative studies being undertaken in these countries so that value in a PM knowledge contribution can be derived from this study and other qualitative research, particularly those that relate to the lived experience of project managers as documented by Hodgson and Cicmil (2006), for example. With globalization increasing and many projects spanning international boundaries perhaps a world-wide survey would be useful?

\section{References}

Besner, C. and Hobbs, B. (2008), "Project management practice, generic or contextual: a reality check", Project Management Journal, Vol. 39 No. 1, pp. 16-33.

Bower, D.C. and Finegan, A.D. (2009), "New approaches in project performance evaluation techniques", Int. J. Managing Projects in Business, Vol. 2 No. 3, pp. 435-44.

Fortune, J. and White, D. (2006), "Framing of project critical success factors by a systems model", Int. J. Project Management, Vol. 24, pp. 53-65.

Hodgson, D. and Cicmil, S. (2006), Making Projects Critical, Palgrave MacMillan, Basingstoke.

Ika, L.A., Diallo, A. and Thuillier, D. (2010), "Project management in the international development industry: the project coordinator's perspective", Int. J. Managing Projects in Business, Vol. 3 No. 1, pp. 61-93.

\section{Current practice in project management}

571 
IJMPB

4,4

572

Khazanchi, D. and Reich, B.H. (2008), "Achieving IT project success through control, measurement, managing expectations, and top management support”, Int. J. Project Management, Vol. 26, p. 699.

Lierni, P.C. and Ribiere, V.M. (2008), "The relationship between improving the management of projects and the use of KM", VINE, Vol. 38 No. 1, pp. 133-46.

Liu, J.Y. and Low, S.P. (2011), "Work-family conflicts experienced by project managers in the Chinese construction industry”, Int. J. Project Management, Vol. 29 No. 2, pp. 117-28.

Mojahed, S. and Aghazadeh, F. (2008), "Major factors influencing productivity of water and wastewater treatment plant construction: evidence from the deep south USA", Int. J. Project Management, Vol. 26 No. 2, pp. 195-202.

Morris, P.W.G., Crawford, L., Hodgson, D., Shepherd, M.M. and Thomas, J. (2006), "Exploring the role of formal bodies of knowledge in defining a profession - the case of project management", Int. J. Project Management, Vol. 24, pp. 710-21.

Murphy, A. and Ledwith, A. (2007), "Project management tools and techniques in high-technology SMEs", Management Research News, Vol. 30 No. 2, pp. 153-66.

Pereira, J., Cerpa, N., Verner, J., Rivas, M. and Procaccino, J.D. (2008), "What do software practitioners really think about project success: a cross-cultural comparison”, The Journal of Systems and Software, No. 81, pp. 897-907.

Raymond, L. and Bergeron, F. (2008), "Project management information systems: an empirical study of their impact on project managers and project success", Int. J. Project Management, Vol. 26, pp. 213-20.

Rosacker, K.M. and Olson, D.L. (2008), "Public sector information system critical success factors", Transforming Government: People, Process and Policy, Vol. 2 No. 1, pp. 60-70.

Sauer, C. and Cuthbertson, C. (2003), "The state of IT project management in the UK 2002-2003", Computer Weekly, April 15.

Shehu, Z. and Akintoye, A. (2010), "Major challenges to the successful implementation and practice of programme management in the construction environment: a critical analysis", Int. J. Project Management, Vol. 28, pp. 26-39.

Standish Group (2009), CHAOS Summary 2009, Standish Group, Boston, MA.

Steinfort, P. (2010), "Understanding the antecedents of project management best practice-lessons to be learned from aid relief projects", $\mathrm{PhD}$ thesis, School of Property, Construction and Project Management, RMIT University, Melbourne.

Steinfort, P. and Walker, D.H.T. (2011), What Enables Project Success: Lessons from Aid Relief Projects, Project Management Institute, Newtown Square, PA.

Thomas, G. and Fernandez, W. (2008), "Success in IT projects: a matter of definition?", Int. J. Project Management, Vol. 26, pp. 733-42.

White, D. and Fortune, J. (2002), "Current practice in project management - an empirical study", Int. J. Project Management, Vol. 20, pp. 1-11.

Wideman, R.M. (2001), The Project Management Institute in the Beginning ..., available at: http://maxwideman.com/papers/pmi/pmi.pdf (accessed 25 November 2010).

\section{Corresponding author}

Joyce Fortune can be contacted at: j.fortune@open.ac.uk

To purchase reprints of this article please e-mail: reprints@emeraldinsight.com Or visit our web site for further details: www.emeraldinsight.com/reprints 